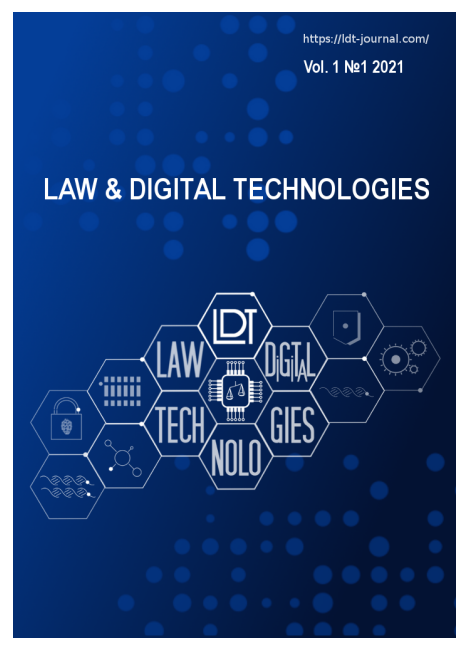

Law \& Digital Technologies. 2013-2023

ISSN 2782--2907

URL - $\underline{\text { http://ldt-journal.com }}$

All right reserved

№ 1 Volume 1. 2021

\title{
Extending Tax Sovereignty to the Internet Space
}

\author{
NIkolay Andreev \\ Law faculty, The State Academic University of Humanities \\ Russian Federation,
}

\begin{abstract}
The article analyzes the extension of tax sovereignty to the Internet space, and describes the legal instruments that regulate the taxation of digital companies and projects. The purpose of the study is to analyze trends in the spread of tax sovereignty to Internet projects and companies, and to find an answer to the question whether it is possible to extend the tax jurisdiction of the state to the Internet. Using historical and legal research methods, the author analyzed the works of researchers on theory of law and taxation and conducted a content analysis of the Organisation for Economic Co-operation and Development (OECD) acts and Russian tax legislation. The author concludes that many states have just begun the process of extending tax sovereignty to the Internet space. Effective tax instruments have not yet been developed, but work is underway in this direction. The author defines this trend as one of the global challenges of modern law.
\end{abstract}

Keywords list (en): Tax, tax sovereignty, tax jurisdiction, taxation of Internet companies, corporate digital tax.

Date of publication: 02.07.2021

\section{Citation link:}

Andreev N. Extending Tax Sovereignty to the Internet Space // Law \& Digital Technologies. - 2021. - V. 1. - № 1 C. 37-45 . URL: https://ldtjournal.com/s123456780015734-8-1/. DOI: 10.18254/S123456780015734-8 
For about a decade, states have been trying to extend their tax sovereignty to the Internet space, and there are examples of states direct and indirect attempts to implement such a policy. An example of indirect attempt is represented by the United States actively fighting with the foreign offices of Google and a number of other IT giants, if these offices are used to avoid taxes. In addition, the location of the company's office on the territory of the relevant state allows to better control such a company and influence its user and information policy. Among the most remarkable examples of direct attempts are the introduction of indirect taxes on digital services (also known as the "Google tax" in Russia), corporate digital taxes, and electronic digital representation. At present, the territorial attribute for establishing sovereignty is not the sole or at least not the main characteristic. Increasingly, in order to collect the above taxes, it is proposed to take into account the nationality of users (e.g., to what country a citizen, whose personal data is collected by the Internet service, belongs to), and the use of certain payment systems. For example, the implementation of electronic currency transfers through the Russian payment service "Yandex Money" may indicate a reason to collect taxes from the income of the electronic platform on which the payment is made using this payment service. To understand the specifics of establishing tax sovereignty or tax jurisdiction in relation to the Internet space, it is necessary first to analyze what tax sovereignty is in general. The next logical step should be studying the issue of extending tax sovereignty to the digital environment. The article analyzes the legal structure of tax sovereignty and studies examples of the extension of tax sovereignty to the digital space (electronic digital representation, indirect tax on digital services, and corporate digital tax).

\section{The Legal Construction of Sovereignty.}

4 Sovereignty is an absolute and permanent state power. Absoluteness in the context of this article should be interpreted as no power exercised above the state (at least from the point of view of jurisprudence). Constancy means that this power is neither interrupted nor can be ceased for a while. The ceased, interrupted power of sovereignty, therefore, cannot be considered. However, we are talking about the origins in the historical perspective. Even in ancient times, there were formally independent states, who had actually lost their sovereignty. As such, the member states of the Athenian Maritime Union paid a tax (foros) to the Attic polis, and obeyed its political decisions. The Roman Republic extended its power to "friendly" states. In other words, the problem of the state independence has existed since ancient times, and was quite closely related to the taxes paid in favor of the actual sovereign. As documented in Russian sources, sovereignty as a supreme power, had practice in collecting taxes. The Chronicle reports on the vocation of the Varangians by the Slovenes, Merei and Krivichi. The latter were ready to submit to the Varangians and pay tribute. The Varangians under the leadership of Oleg, Russian prince in the IX century, extended their power to many tribes, forcibly imposing tribute on them, thus subjugating those tribes: "And many countries of attraction to the Russian land and lay tribute on them" (Chronicle collection, called the Patriarch or Nikon Chronicle by publisher, 9). It is obvious that the main instrument of submission was the payment of tribute. Perhaps, for the medieval compiler of the Chronicle this procedure was a necessary symbol of the sovereignty extension of the Old Russian state to new lands and peoples. Next, we would like to illustrtate that the loss of the ability to collect taxes is considered as a sign of the loss of sovereignty. To explain the tax sovereignty in the domestic legal science, a 
number of definitions are proposed. Khavanova (2013) understands fiscal (tax) sovereignty as "the legitimate and unlimited right of the state to set taxes". Omelekhina (2014) understands fiscal sovereignty as "the legally unlimited right of the state to demand from its subjects active actions to participate in the formation of the necessary resources". Sadchikov (2016) defines sovereignty as "the exclusive right of the state to independently perform the function of taxation and tax collection within the territory to which its jurisdiction extends". All these authors somehow connect tax sovereignty with law (relatively speaking, the subjective law. Moreover, the content of this right is severely restricted. This is the right only to collect taxes or the right to demand from the population active actions for the formation of the necessary resources (although these actions may not be related to the payment of taxes, which creates some ambiguity in the content of the concept). This can also be the right to impose a tax (interestingly, the right to levy or to bring to tax liability is not mentioned). Such narrowing of the content of tax sovereignty seems to us unjustified. At the very least, this contradicts the very meaning of the term "absolute power". Such power may establish any list of rights that it may exercise, otherwise it will not be absolute. Instead, tax sovereignty should be seen as the foundation on which the state's tax powers are built. If necessary, some elements may be removed, while others be included, and this process will not change the basis of such a legal structure. In our opinion, this suggests that tax sovereignty is the basis of the tax legal personality of the state, the source of its origin. It is important to name the difference in application of the terms. Legal personality initially indicated the possibility of approximately equal status (primarily property) of persons to enter into certain legal relations. In Roman law, where legal scholars used to form the concept of legal personality, much more attention was paid to the relationship of individuals and, to a lesser extent, legal entities. Legal personality was intended to determine the place of an individual or legal entity in communication with a variety of other individuals and legal entities. The Roman state, however, did not have any equivalent subjects in the legal field. In Roman law of the Republican period, the state was defined as a civitas, i.e., a community of citizens, and it would be illogical to contrast citizens with themselves. To designate the state as a subject of private law, the concept of fisk and treasury was introduced. The Roman state was not considered as a legal entity, and the laws, governing transactions made on behalf of the state, were acts of competence of the relevant magistrates. Thus, the legal personality as a legal structure was associated rather with magistrates exercising the authority to conclude civil transactions, and later was extended to the state, without taking into account the peculiarities of its legal status. In addition, the Romans used a special term "imperium" for the public powers of the state. By imperium the Romans understood unlimited, absolute power, having its foundation in itself, that is, it was a power in itself aimed at maintaining the existence of a common cause - "res publicum" and belonging to the Senate. The latter could transfer the imperium to the magistrates for a certain time. In many ways, the imperium served as a prototype of the construction of sovereignty (Andreev 2012). In Modern times, in order to finally separate the power of the German emperor and the European kings, as well as to secure the power over the local feudal lords, the concept of sovereignty arose. The concept of sovereignty is still used today (Andreev 2012). However, purely political needs, for example, the need to define the hierarchy of feudal lords in Europe, led to the consolidation of the same political content. This is seen from Jean Baudin's definition of sovereignty as a permanent, supreme, independent, unbound by laws, absolute power 
over citizens and subjects. The emphasis in this definition is on the independence and absoluteness of power. The legal content of this power was practically not taken into account since Boden did not set such a goal (Lazarevskiy 2008). Thus, it can be noted that the legal definition of sovereignty cannot be formulated only from the analysis of the political content. The solution of the problem seems to be in determining the functions of sovereignty as a legal phenomenon. Thus, we can come to the following conclusions: - tax sovereignty should be considered in three aspects; - under the legal aspect of tax sovereignty, it is necessary to understand the basis of the tax legal personality of the state; - the political aspect of tax sovereignty should be understood as the ability and real independence in the state's decision-making in the field of taxation; the economic aspect of tax sovereignty should be understood as the material ability to ensure the implementation of state actions in the field of taxation; - the combination of all three aspects allows us to talk about the presence of tax sovereignty, while its absence questions state capacity to act freely in regulating tax relations. If there is a legal personality, we can talk about the existence of a legal entity, otherwise there is no legal entity. Sovereignty (especially, tax sovereignty) and tax jurisdiction is a complex phenomenon that has many legal aspects (Palienko 1903). Vinnitskiy (2017) believes that in relation to tax sovereignty, it is necessary to distinguish between material and procedural aspects. The researcher believes that in the conditions of international integration, the prerequisites for the fragmentation of law in space are created, when one tax system seeks to reject the elements of another national tax system. However, the participants of the world community "are aware of the need to limit their own sovereignty". In the context of economic integration within the framework of supranational unions, various concepts of such self-limitation arise. Also, most of these concepts require to distinguish between the territorial limits of tax sovereignty and the scope of tax jurisdiction. Gidirim (2018), for example, draws attention to the fact that jurisdiction is "the competence of states under international law to create domestic legislation". Vinnitskiy (2017) defines jurisdiction as the right to regulate. A comprehensive definition of tax jurisdiction was given in the second revision of the legislation on international relations of the United States: "Jurisdiction is the ability of a state under international law to prescribe and apply a rule of law". Gidirim (2018) distinguishes three types of tax jurisdiction: prescriptive (legislative), judicial and executive. Prescriptive tax jurisdiction includes the right of the state to set binding rules. Judicial jurisdiction is the ability to resolve tax disputes. Executive jurisdiction is the ability to conduct tax investigations and forcibly collect taxes, including from a taxpayer located outside the relevant state. Vinnitskiy (2017) identifies three groups of factors that determine the ability to exercise jurisdiction in each specific case: 1) subject factors; 2) object factors; and 3) object-territorial factors. The researcher considers residence, domicile, and the place of management of the enterprise (a company) to be subject factors. The author defines the object as the concept of the source of income (profit) of the taxpayer and a permanent establishment. To the object-territorial - the location of the property, the territory of transit. Gidirim (2018) defines tax jurisdiction as the competence to establish and collect taxes, including the resolution of tax disputes, as well as the right to enforce tax obligations in case of tax violations. Depending on the importance of the tax jurisdiction components in a particular case, the researcher distinguishes three different tax sovereignties: 1) personal sovereignty; 2) territorial sovereignty; and 3) functional sovereignty. Personal sovereignty is the supreme 
authority of the state over citizens and organizations, including the right to extend its laws to these entities, wherever they may be located. Personal sovereignty is most pronounced in American tax law: according to US tax law, US citizens must pay taxes regardless of where those taxes were received. Territorial sovereignty is the supreme authority of the state over all persons and things that are located within the territory of the state. Functional sovereignty is a limited exercise of sovereignty: when a state does not have full sovereignty, it is still entitled to exercise some sovereign rights. An example of the implementation of functional sovereignty is the use of an exclusive economic zone. In the water area adjacent to the territorial waters, the state exercises certain sovereign rights. In the context of functioning of economic unions, states are forced to take into account all these international legal aspects of tax sovereignty and tax jurisdiction. Moreover, (in the context of OECD) it becomes impossible to consider only the tax sovereignty of the Russian Federation. As a key member of the Eurasian Economic Union, our state is self-limiting its sovereign tax rights in order to ensure the implementation of supranational acts, and is involved in the processes of tax integration and competition.

\section{Tax Sovereignty Follows the Economic Interests of the State.}

6 Tax sovereignty is often associated with a certain territory. The vast majority of the instruments of the Tax Code of the Russian Federation is linked to a specific territory (such as place of registration, residence, etc.). However, in the context of the development of e-commerce, carried out mainly through the Internet, there are difficulties with determining the specific territory to which a particular action could be linked, as well as with judicial jurisdiction, in the event of relevant disputes. For instance, in the United States and the European Union, it is determined whether the use of a website is directed to the relevant territory in order to establish, for example, judicial jurisdiction (Saveliev 2016). This "digital" aspect of tax sovereignty will be further discussed in detail. The content of the tax legal capacity of the Russian Federation, as a specific subject of financial law (along with individual and collective subjects), is closely related to the implementation of the financial activities of the state within the competence provided by the norms of the Constitution of the Russian Federation, the Tax Code of the Russian Federation, the Budget Code of the Russian Federation, Constitutions, charters of the subjects of the Russian Federation and other sources of financial law. As a subject of material budgetary rights, the Russian Federation acts simultaneously as a sovereign state and a treasury state. As a subject of financial law, the Russian state has the right to establish and collect federal taxes and fees. According to paragraph " $z$ " of Article 71 of the Constitution of the Russian Federation, the Russian Federation is responsible for federal taxes and fees (Dreval 2008). As stated in Article 2 of the Tax Code of the Russian Federation, the legislation on taxes and fees regulates power relations for the establishment, introduction and collection of taxes and fees in the Russian Federation, as well as relations arising in the process of tax control, appealing against acts of tax authorities, actions (inaction) of their officials and bringing to justice for committing a tax offense (Karaseva 1997). It is the actions of the federal legislator that determine the balance of the tax system, the stability and predictability of the amount of revenue available to public authorities. In our opinion, the general principles of taxation in our country also belong to the jurisdiction of the Russian Federation, despite being referred to the subject of joint jurisdiction under 
Article 72 of the Constitution of the Russian Federation. The right to change the Tax Code belongs to the federal legislator, who can bring any changes to the text of the code, establish or exclude any principle from the text of the law, which was a case with the principle of tax fairness. The Constitutional Court of the Russian Federation has repeatedly pointed out at the above situation. Taxes are the basis of the fiscal sovereignty of the Russian Federation as a whole, and the well-being of the state depends on timely tax receipts, while the subjects of the federation are deprived of sovereignty. For this reason, the Russian Federation should establish the rules of tax law, and not transfer part of these powers to the level of subjects (Khudiakov 2010). It seems that granting the right to set taxes to the Russian Federation as a whole is a reasonable effort of the legislator from both legal and economic positions. Article 8 of the Constitution of the Russian Federation states that the unity of the economic space, free movement of goods, services and financial resources is guaranteed in the Russian Federation. However, such unity is impossible if different taxes are applied in different regions of the country. In addition, the tax is directly related to the sovereignty of the state, and the rights to establish it derive from fiscal sovereignty, while the subjects of the Federation do not have sovereignty. The latter quality allows the subjects of the Federation to have rights and obligations in the tax sphere but deprives them from being equal in scope to the rights of the Russian Federation (Bobkova 2007). The tax legal personality of the Russian Federation is the ability of a sovereign Russian state to adopt tax laws, to provide for the subject and object composition of taxation, to establish the principles of taxation, to be a subject of tax law and tax legal relations, including the legal ability to collect taxes, to organize control over the performance of tax duties, to bring violators to tax liability, and to compensate for damage caused by illegal actions of state bodies in the field of taxation. The tax legal personality of the Russian state is manifested precisely in the public sphere of activity in the exercise of its powers related to the establishment and collection of state taxes. The state cannot fail to recognize itself as a subject of law. It always exercises its power in legal forms, not because it wants to, but because it cannot do otherwise. The state acts and exists through law, and only the subject can act with the help of law. Consequently, the state cannot deprive itself of its legal personality without ceasing to be a state. Also, the state cannot recognize an equal amount of legal personality for another subject (on the territory of this state); otherwise, a second state will appear on the same territory. This provision follows from the international legal principle of the sovereign equality of states. To renounce legal capacity means to renounce sovereignty, and vice versa (Palienko 1908). In addition to the question on the right to establish and impose taxes, there is also a controversy in the literature on whether the Russian Federation has the right to levy taxes. Thus, some researchers point out that the collection of taxes is the authority of the tax authorities. However, it seems incorrect to separate the power to establish a tax and the power to levy a tax. The establishment of taxes is initially intended to ensure that the established taxes are collected, and therefore, the power to collect should be considered as part of the power to establish. Here we can draw a parallel with the subjective right (as discussed in more detail above): the right also includes the right to protection, and to demand the enforcement of the relevant right. Therefore, the power to levy should be attributed either to one of the powers of the state or considered as part of the power to establish (Jellinek 2004; Ivanov 2010). The payment of taxes is not a form of restriction of the owner's constitutional right. The restriction of the right of ownership is expressed 
in the restriction (reduction in the scope) of the owner's powers in connection with the elasticity of ownership and ownership rights. The owner's constitutional and legal obligation to pay taxes is not a restriction of their powers, but the imposition of the burden (obligation) for the maintenance of their own property, including the public legal obligation to pay taxes, on the owner themselves. Taking into account the modern doctrine of tax law and analyzing tax legislation, including the norm of Article 8 of the Tax Code of the Russian Federation (Kamyshanskiy 2000), the essential features of taxes as a legal entity are publicity, purpose, obligation, compulsion, property nature, individual gratuitousness, irrevocability, the procedure for paying and collecting taxes provided for by law. Kucherov (2009) notes their legality and abstractness (inappropriate use) as an essential feature of taxes. However, in our opinion, legality is not a sign of a tax but serves as a principle of taxation: the establishment, payment and compulsory collection of taxes, as well as bringing to tax liability, should be carried out only on the basis of the law and in accordance with the law. As for the second feature (purposelessness), in our opinion, all taxes have a strictly targeted purpose. As stated in Part 1 of Article 8 of the Tax Code of the Russian Federation, a tax is a payment of funds "for the purpose of financial support for the activities of the state and (or) municipalities" (Kucherov 2009). Moreover, the so-called target taxes (taxes on vehicles, road taxes, etc.) have a special purpose (Sokolova 2009). The publicity of the tax is also manifested in the methods of tax legal regulation, which are associated with the application to a greater extent of norms of a binding (authoritative) nature, mandatory norms, norms-prescriptions, prohibitions, and non norm-permits, as is the case in private law. As might be expected, the publicity of taxes and taxation is due to the purpose of taxes, their economic role for the state and the implementation of the majority of existing national functions. Back in 1996, in one of its Rulings, the Constitutional Court of the Russian Federation emphasized that tax is a necessary condition for the existence of the state, and the obligation to pay taxes, enshrined in Article 57 of the Constitution of the Russian Federation, applies to all taxpayers as an unconditional requirement of the state. This duty of taxpayers (including citizens engaged in business activities with the formation of a legal entity) embodies the public interest of all members of society. Therefore, the state has the right and obligation to take measures to regulate tax legal relations in order to protect the rights and legitimate interests of not only taxpayers, but also of other members of society. In other words, tax legal relations are public and legal, since their implementation is aimed at satisfying the public interests, that is, the interests of the entire society (Karaseva and Shchekin 2009). In 2004, the Constitutional Court of the Russian Federation stated that "taxes that have a public purpose are a necessary economic basis for the existence and activity of the state, a condition for the implementation of these public functions, and the obligation to pay legally established taxes and fees applies to all taxpayers as an immediate requirement of the Constitution of the Russian Federation (Article 57)" (Decision of the Constitutional Court of the Russian Federation. No. 14-P. July 16, 2004.). In Resolution No. 12 of June 17, 2004, The Constitutional Court of the Russian Federation drew attention to the public-legal nature of the regulation of budgetary relations, which act as an economic expression of the sovereignty of the state, the material basis for exercising of public functions and powers of the Russian Federation, and the subjects of the Russian Federation and municipalities. 
The Russian Federation actively extends its sovereignty and its economic influence on the digital environment. The huge revenues generated by Internet companies force Russia to take into account the state's economic interests, the needs of the treasury and impose tax sovereignty in the digital environment. Concurrently, Russia, as well as a number of other states, face difficulties. For example, the usual structures of a permanent establishment, a place of income, a center of vital interests do not always correspond to the features of e-commerce. Thus, it is very difficult to determine the place of income if the office, that accepts payment in one country, places ads on sites in dozens of domain zones, and people who are not located in the corresponding domain zones make payments for this advertising. Another example is when giant aggregators or marketplaces, such as Alibaba, are located in one country, but a significant share of sales is carried out outside of it. As might be expected, the state where these sales are made will be interested in taxing the income from these sales (Khavanova 2017a). Currently, there is a problem of extending tax sovereignty, at least in the legal sense (OECD 2017). It is very difficult to extend the jurisdiction in which the legal aspect of sovereignty is implemented to something very unusual (for state bodies). Changing the binding to the space one can quickly change the server, the place of registration of the organization, and so on. At the same time, the objective need to fill the treasury requires The problem of taxation of electronic (digital) commerce is increasingly attracting attention. For example, in November 1997, the OECD held conferences on barriers to global e-commerce (OECD 1997), and in 2015 and 2018, joint papers of the OECD and the G-20 were published (OECD 2015, 2018). They addressed the issue of electronic representation (digital permanent representation) (Andreev 2018). The issue of tax sovereignty and the discussions around permanent and electronic representation are acute topics. At the moment, it is easier to extend the effect of tax sovereignty (in particular, tax jurisdiction) to a permanent establishment, since for ordinary commerce with the participation of foreign organizations and individuals, the practice of taxation of a permanent establishment is the most developed and understandable. Similarly, the domestic tax authorities, in general, have worked out the mechanisms of administration using the design of a permanent representative office. At present, there is a debate between supporters of the conventional design of permanent representation, on the one hand and supporters of electronic representation, on the other. Thus, Khusnetdinov (2011) proves the possibility of using the institution of permanent representation in direct taxation of participants in electronic business activities. Apparently, Frolova (2009), another supporter of the usual design of a permanent representation, points out that practical implementation takes time. Kastelskaya (2005), analyses international experience and problems of the classical concept of a permanent representation and does not support the idea of electronic representation. Ismayilov (2015) acknowledges the need to use different criteria in determining the country of location of the permanent representation, including addressing the issues of server placement. Danilkevich (2013) emphasizes the problems of the classical design of the permanent representation, but does not offer an alternative, except for restricting the import of goods purchased by individuals. Kadyleva (2012) suggests considering the provider and/or hosting provider as dependent on the subject of e-commerce agent and permanent representation. Konnov (2002) postulates an approach similar to the definition of a permanent establishment for international transport to the taxation of electronic commerce, and poses choosing the most preferred place of income generation. 
An intermediate position, in our opinion, belongs to Skachkov (2004). He justifiably points out that it is impossible to apply the classical criteria of a permanent establishment to e-commerce, but considers it imperative that a physical presence is necessary for the formation of a permanent establishment. The above-mentioned conference of 1997 opened up the possibility of establishing tax representation. The conference materials discussed the problems of e-commerce and taxation, and presented the idea of e-representation. Though over two decades has passed since the conference was held, e-representation still remains more a cause for reflection than a solved problem. Koren (2011) highlights the immateriality of e-commerce representation. The author defends the idea of the three criteria for determining the jurisdiction of a permanent establishment: registration criteria (registration in the corresponding domain zone), language criteria, and consumer criteria (the territory from where the main volume of payments is provided). We consider it appropriate to discuss the position of the OECD, which has become a "skirmisher" in the discussion of a digital permanent representation design. The OECD has formulated the position that a permanent establishment should be set up in the country with the localized website and specialized equipment designed to serve e-commerce activities. This criterion introduces an novelty by complementing the three main criteria for determining a company's residency. In addition, the 2018 OECD Interim Report outlined three factors to consider when determining digital representation: the factor of revenue generated, the factor of digital presence (for example, a local domain name or a specific payment method), and the factor of the number of users. In our opinion, at a minimum, fiscal interests require the recognition of the design of a digital permanent representation, taking into account the three criteria proposed by the OECD. Based on these criteria, we formulate the concept of digital permanent representation. For the basic concept for a permanent establishment, we draw on the OECD Model Convention on Taxes on Income and Capital framing (Rozdestvenskaya and Guznova 2017). In this Convention, the OECD defines a permanent establishment "as a fixed place of business through which an enterprise conducts its activities in whole or in part, including a place of management, a branch, an office, a factory, a plant, a mine, a drilling rig, a quarry or other place of extraction of natural resources, a construction site, a construction or assembly facility, and dependent agents" (Danilenko n.d.). This concept has long been inconsistent with the needs of e-commerce, except for the reference to the place of management, which is indicated at least by the factors proposed by the OECD itself. National regulators, in turn, are still only at the stage of comprehending the relevant problems. The addition of an already existing concept is seen as an unnecessary accumulation of factors (which is obvious from the definition provided above); furthermore, the features of e-commerce itself require a special approach. In this regard, a simple addition seems ineffective. It seems that the easiest way would be to create a special definition for an electronic digital representation, and to define it as "the place of activity through which the enterprise fully or partially conducts its activities, including the state or territory of the digital presence, in which it has the main source of users, the place of receipt of the main income" (Khavanova 2017b). The preservation of the term "place" is caused by the fact that, indeed, for the modern system of tax administration, a territorial reference is required. Otherwise, it will not be possible to apply the measures of influence that will be required to force the taxpayer to pay the tax. As a reverse example, we can use the "Google tax". According to the Federal Tax Service, as of February 2018, 143 major 
foreign organizations voluntarily registered as VAT (Value Added Tax) payers, and the proceeds for 2017 were estimated at 9.4 billion rubles (Regnum 2018). It is quite easy to determine the amount of trade transactions executed by these companies based on the amount of VAT. But these are only indirect taxes, whereas very significant amounts of direct taxes can be extracted if the digital permanent establishment design is properly implemented. On a global scale, the e-commerce market, for example, in the B2B sector (contracts of entrepreneurs with entrepreneurs) in 2017 was estimated at $\$ 7.66$ trillion, and in the B2C sector (transactions between entrepreneurs and consumers) at \$2.143 trillion. In Russia, the volume of e-commerce at the end of 2017 was estimated at about 1.1 trillion rubles, although estimates were made of the growth of these volumes to 5-7 trillion in the foreseeable future (Podguzov 2018). If you use old designs that are not optimized for the conditions of the digital economy, the treasury will lose very significant tax revenues: it will not be legally possible to tax the corresponding operations. The introduction of the concept of "digital permanent establishment" will also require the creation of legal instruments for tax administration. Many site servers whose main activity is connected with Russia can be registered, for example, in Ecuador, which, in accordance with the Order of the Federal Tax Service of 01.09.2017 No. MMV-7-17/709@, does not provide information exchange with the Federal Tax Service. There are over a hundred such states, in addition to two dozen territories. The process of tax information exchange is difficult, let alone effective tax enforcement (even the "Google tax" is paid by voluntarily registered organizations). Hence, even with the extension of legal sovereignty (through the consolidation of the concept of digital permanent representation), there will be economic and political issues. In future works, we plan to propose appropriate mechanisms that will ensure the full extension of tax sovereignty to e-commerce carried out in Russia or with the participation of Russian consumers. Since the end of the 2010s, the issue of digital sovereignty has become increasingly relevant for the Russian Federation. In addition to the introduction of the "Google tax", in the spring of 2021, a reform to consolidate the corporate digital tax also began. The corporate digital tax was originally proposed by the OECD as one of the elements of the tax reform of electronic digital products (along with digital representation). Under the corporate digital tax model, a digital company that provides users from other countries (including sites registered in foreign domain zones) with digital services whose turnover exceeds a certain figure (for example, $\$ 300$ million per year) is required to pay taxes at the company's place of registration on all "digital" income (or global digital income), regardless of the territory on which they are received. A similar legal model of corporate digital tax is planned to be introduced in Russia. At the same time, foreign companies that provide electronic services or engage in ecommerce for users from the territory of the Russian Federation will be subject to it. The only key parameter for determining whether a company has received income related to Russia will be the question of personal data use. If a foreign company uses, stores, or at least collects personal data of Russian citizens, this will be a key basis for collecting corporate digital tax from a foreign company. Altogether, the mechanisms for collecting such a tax are still unclear. For example, the indirect tax on electronic services (Google tax) is currently subject to the voluntary declaration of income from transactions by a foreign company. In the event that a foreign company does not file tax reports as a payer of indirect tax on electronic services, the Russian tax authorities will not be able to forcibly recover the amount of indirect tax. In the case of indirect taxes, the mechanism 
for calculating the amount of tax becomes simpler through determining the percentage of the transaction amount and payment for electronic service, but in calculating corporate tax (income tax), the company's expenses should usually be taken into account as well. However, in a simple transfer of calculating tax from indirect tax to corporate tax, it will essentially be the same tax under different names. The Group of Seven (G7) countries offer a simpler, but no less burdensome way to impose a global single tax on companies, including IT giants: in all countries of the world (at least those who join the initiative) to set a single rate of $15 \%$ on the company's income. Furthermore, a higher number of local offices will involve a higher tax burden. Nevertheless, it is not necessary for an IT company to have offices in the residing countries of digital services buyers and consumers. By and large, they can work without an office and without registering a legal entity.

9 Conclusion So far, states and supranational structures (for example, the OECD) have not formulated clear approaches to solving the problem of corporate taxation of IT companies. This shows that there are no optimal legal tools for extending tax sovereignty to the Internet environment, which does not mean there will not be any legal tools. The economic needs of sovereign states, and the efforts to extend taxation on income from e-commerce will soon lead to the creation of the appropriate legal instruments. To not lose the opportunity to conduct e-commerce and to avoid excessive tax burden will be a real challenge for the IT business. Apparently, we will witness a struggle in the field of tax law between tax sovereigns and IT companies. 


\section{Andreev NIkolay}

\section{Аннотация}

Ключевые слова:

Дата публикации: 02.07.2021

\section{Ссылка для цитирования:}

Andreev N. // Law \& Digital Technologies. - 2021. - T. 1. - Vol. 1 №1 C. 37-45 . URL: https://ldt-journal.com/s123456780015734-8-1/. DOI: $10.18254 / \mathrm{S} 123456780015734-8$ 